\title{
Model Pelatihan untuk Meningkatkan Kompetensi Guru Pendidikan Agama Islam Sekolah Dasar
}

\section{Competency Improvement Training Model for Elementary School Islamic Religious Education Teachers}

Received: 16-05-2019; Revised: 30-11-2020; Accepted: 03-12-2020; Published: 31-12-2020

\section{Fadriati *)}

Institut Agama Islam Negeri Batusangkar, Sumatera Barat, Indonesia E-mail: fadriati@iainbatusangkar.ac.id

*) Corresponding Author

\begin{abstract}
One of the problems in educational sector in Indonesia today is the low competence of Elementary School Islamic Religious Education teachers in their instruction. Therefore, efforts to increase their competence need to be realized. One of the efforts can be pursued through quality education and training programs. This research is aimed at producing a training model for education and teacher training provider and finding out the level of validity of the developed model in improving the competence of Elementary School Islamic Religious Education teachers. The type of the research is $R \& D$ which applies Gall and Borg development model. Data sources are training implementers at the teacher training agency of West Sumatera Regional Religious Education Center (Balai Diklat Keagamaan Wilayah Sumatera Barat) in Padang, namely: the Head of Division of Elementary School Islamic Religious Education (Kepala Bidang PAI SD), and he Head of the Sumatera Regional Religious Education and Training Center in Padang, and the PLPG Implementation Committee for Elementary School Islamic Religious Education teachers at the Tarbiyah Faculty and Teacher Training Center of IAIN Imam Bonjol Padang. Data were collected through observation, interview, Focused Group Discussion, and expert judgment and questionnaires. Qualitative data were analyzed with the interactive model of Miles and Huberman. Quantitative data were analyzed with descriptive statistics. The research results showed that the education and training for teachers refers to the centralized model guide The results of the validation of the training model were $80.07 \%$ with a very valid category.
\end{abstract}

\begin{abstract}
Abstrak: Salah satu permasalahan dunia pendidikan di Indonesia saat ini adalah masih rendahnya kompetensi guru PAI SD dalam melaksanakan pembelajaran sesuai kebutuhan. Oleh sebab itu, upaya-upaya peningkatan kompetensi pendidik perlu dilakukan. Salah satu upaya dimaksud dapat ditempuh melalui program pendidikan dan pelatihan (diklat) yang berkualitas. Penelitian bertujuan untuk menghasilkan model pelatihan bagi lembaga pelaksana Pendidikan dan pelatihan guru dan mengetahui tingkat validitas model dalam meningkatkan kompetensi guru PAI SD. Jenis penelitian yang digunakan adalah $R$ \& $D$ dengan menerapkan model pengembangan Gall and Borg. Sumber data penelitian adalah pihak pelaksana pelatihan pada instansi
\end{abstract}


pelaksana pelatihan guru, yaitu: Kepala Bidang PAI SD, dan Kepala Balai Diklat Keagamaan Wilayah Sumatera di Padang serta Panitia Pelaksana PLPG bagi guru PAI SD di Fakutas Tarbiyah dan Keguruan IAIN Imam Bonjol Padang. Data penelitian dikumpulkan dengan Teknik observasi, wawancara, Focus Group Discussion, meminta expert judgement dan penyebaran angket. Teknik analisis data kualitatif yang digunakan adalah model interaktif. Miles and Huberman. Teknik analisis data kuanitatif menggunakan statistik deskriptif. Hasil penelitian menunjukkan bahwa pendidikan dan pelatihan bagi guru mengacu kepada panduan model secara terpusat. Hasil validasi model pelatihan adalah $80,07 \%$ dengan kategori sangat valid.

Keywords: Training models, teachers competence, islamic teacher

\section{PENDAHULUAN}

$\mathrm{G}$ uru yang idealis dituntut memiliki dedikasi yang tinggi dan kinerja profesional sesuai dengan tuntutan ilmu pengetahuan, teknologi dan perkembangan masyarakat (Nurdin \& Adriantoni, 2016). Kenyataan yang ditemukan pada beberapa lembaga pendidikan adalah kompetensi guru masih dalam kategori cukup (Deni Suhandi dan Julia, 2014). Pola pelatihan masih konvensional dan sulit menjangkau seluruh guru. Pelatihan yang diterima guru masih sampai pada tahap pemahaman belum sampai pada tahap teknis dan praktis (Fitria, Dkk.: 2019). Masih adanya guru yang mengajar tidak sesuai dengan latar belakang keilmuan, model pelatihan yang dilaksanakan belum dapat meningkatkan kompetensi guru secara maksimal dan belum sesuai dengan karakter guru PAI Sekolah Dasar.

Penyebab rendahnya mutu pembelajaran antara lain, karena pada umumnya guru bekerja sendiri dalam mempersiapkan dan melaksanakan pembelajaran. Guru yang kreatif dan inovatif belum mampu mempengaruhi guru lain, karena tidak ada sharing di antara guru. Akibatnya, apabila guru yang kreatif dan inovatif pensiun, maka kreatifitas dan inovatif itu hilang pula. Model pembinaan guru yang telah dilakukan baru sebatas menyampaian materi dan tidak ditindaklanjuti dengan praktek dan pendampingan (Subadi \& Dahroni, 2017).
Keberadaan guru sebagai pusat reformasi pendidikan dan peradaban, harus terpenuhi secara kuantitas dan kualitas. Hal ini bertujuan untuk mendorong reformasi kualitas guru. Kualitas guru sekaligus menjadi parameter kualitas pembelajaran (Chew, 2016). Atas dasar ini, maka kompetensi guru harus ditingkatkan. Persoalan mutu pendidikan merupakan hal yang paling penting dan harus diantisipasi dalam mengembangkan suatu lembaga. Peningkatan kompetensi guru dapat ditempuh melalui pelatihan. Target pelatihan adalah untuk meningkatkan produktivitas kerja saat ini, sedangkan target pengembangan adalah untuk meningkatkan produktivitas saat ini dan masa yang akan datang (Anisah, 2014: 1).

Penelitian ini bertujuan untuk menghasilkan model pelatihan yang valid untuk meningkatkan kompetensi guru Pendidikan Agama Islam Sekolah Dasar. Perancangan model pelatihan guru Pendidikan Agama Islam bermanfaat untuk meningkatkan kualitas pelatihan. Model pelatihan guru yang inovatif dan kreatif akan berpengaruh terhadap keberhasilan pelatihan guru. Desain model pelatihan dikembangkan secara baik dan tahapan yang benar, akan berpeluang besar dapat digunakan secara maksimal dan dapat meningkatkan kualitas pelatihan. Apabila kualitas pelatihan guru meningkat diharapkan akan dapat meningkatkan kompetensi guru. 
Berdasarkan pertimbangan di atas dan untuk mencapai hasil pembelajaran yang maksimal perlu dikembangkan model pelatihan yang sesuai dengan karakter guru Pendidikan Agama Islam, memiliki landasan konseptual dan memiliki pedoman operasional yang jelas. Model pelatihan yang dikembangkan harus dapat meningkatkan kompetensi guru Pendidikan Agama Islam Sekolah Dasar di Sumatera Barat.

Pelatihan guru berguna untuk mengembangkan kompetensi profesional guru serta meningkatkan kecakapan dalam hal pengetahuan, pengalaman, sikap, nilainilai, moral dan keterampilan mereka (Carr, 1999). Pelatihan guru konvensional tidak memiliki fokus pengajaran praktis dan cenderung sulit untuk diterapkan. Pelatihan tradisional lebih cenderung menggunakan metode ceramah, seminar, dan diskusi kelompok (Akarawang, Kidrakran, \& Nungchalerm, 2017).

\section{METODE PENELITIAN}

Metode penelitian yang digunakan adalah metode peneltian dan pengembangan. Disain pengembangan digunakan adalah disain pengembangan yang dikemukakan oleh Gall and Borg. Pada model Gall and Borg ada 10 (sepuluh) langkah penelitian dan pengembangan, yaitu (1) Research and information collecting, (2) Planning, (3) Develop preliminary form product, (4) Preliminary field testing, (5) Main product revision, (6) Main field testing, (7) Operational product revision, Operational field testing, (9) Final product revison, (10) Dissemination and implementation (Gall \& Borg, 2003).

Pada model yang dikemukakan Gall and Borg, setiap langkah penelitian pengembangan mempunyai kaitan yang erat satu sama lain. Pada penelitian tesis dan disertasi Gall and Borg menyarankan untuk membatasi penelitian pada skala kecil, termasuk kemungkinan membatasi langkah penelitian. Penelitian ini dirancang menggunakan langkah yang diyakini telah memenuhi untuk dapat menghasilkan model pelatihan untuk meningkatkan kompetensi guru PAI Sekolah Dasar.

Penelitian ini menggunakan sepuluh tahapan penelitian dan pengembangan sebagaimana berikut:

\section{Tabel 1. Tahapan Penelitian dan Pengembangan Model Pelatihan}

\begin{tabular}{|c|c|c|}
\hline 1. & Studi Kepustakaan & $\begin{array}{l}\text { Mengumpulkan informasi berupa konsep dan teori yang berhubungan } \\
\text { pelatihan guru yang relevan dengan model yang dikembangkan. Dilakukan } \\
\text { secara berkesinambungan mulai dari tahap perencanaan, pengumpulan } \\
\text { data, perancangan, analisis data, validasi dan finalisasi model. }\end{array}$ \\
\hline 2. & $\begin{array}{l}\text { Mengumpulkan data } \text { dan } \\
\text { kebutuhan }\end{array}$ & $\begin{array}{l}\text { Melakukan studi lapangan untuk mengumpulkan data tentang model } \\
\text { pelatihan yang sudah berlangsung bagi guru Pendidikan Agama Islam di } \\
\text { Sumatera Barat, faktor pendukung dan penghambat serta upaya yang } \\
\text { dilaakukan untuk meningkatkan mutu pelatihan guru. Penelitian lapagan } \\
\text { dilakukan pada lembaga pelaksana pelatihan guru PAI, yaitu Kantor } \\
\text { Wilayah Kementrian Agama Provinsi Sumatera Barat sebagai pelaksana } \\
\text { Bimbingan Teknis Kurikulum } 2013 \text { bagi guru PAI SD, Balai Diklat } \\
\text { Kementerian Agama Wilayah Sumatera sebagai pelaksana pendidikan dan } \\
\text { Latihan teknis Fungsional Peningkatan Kompetensi Guru PAI SD dan } \\
\text { Fakultas Tarbiyah dan Keguruan IAIN Imam Bonjol Padang sebagai } \\
\text { pelaksana Pendidikan dan Latihan Profesi Guru (PLPG). }\end{array}$ \\
\hline 3. & Merancang prototipe awal & $\begin{array}{l}\text { Membuat perencanaan model dengan melakukan analisis terhadap data di } \\
\text { lapangan (need analysis). Model pelatihan guru dirancang berdasarkan data } \\
\text { dan informasi yang diperoleh melalui penelitian lapangan untuk } \\
\text { mengetahui analisis kebutuhan serta mengacu pada konsep dan teori yang } \\
\text { diperoleh tentang model pelatihan guru. Prototipe model awal dihasilkan } \\
\text { dihasilkan melalui tahap diskusi dan diskusi dengan pakar dan praktisi } \\
\text { pelatihan guru. }\end{array}$ \\
\hline 4. & Focus Group Discussion I & $\begin{array}{l}\text { Kegiatan kelompok diskusi yang diikuti oleh unsur terkait dan kompeten, } \\
\text { yaitu para ahli, pelaksana pelatihan guru dan pihak terkait yang } \\
\text { memberikan kontribusi pemikiran dan masukan penting sebagai bahan } \\
\text { untuk menyempurnakan model awal. }\end{array}$ \\
\hline 5 . & Revisi I & $\begin{array}{l}\text { Perbaikan draf model berdasarkan masukan, pandangan dan pertimbangan } \\
\text { dari peserta FGD I untuk menyempurnakan menjadi draf model ke II. }\end{array}$ \\
\hline 6. & Focus Group Discussion II & $\begin{array}{l}\text { Diskusi kelompok tahap kedua untuk meminta masukan dari pakar, } \\
\text { pelaksana pelatihan dan pihak terkait lainnya untuk memberikan masukan } \\
\text { dan menyempurnakan draf model II. Masukan yang diperoleh pada FGD II }\end{array}$ \\
\hline
\end{tabular}




\begin{tabular}{|l|l|l|}
\hline & & merupakan bahan untuk menyempurnakan model yang dihasilkan. \\
\hline 7. & Revisi II & Melakukan perbaikan draf model II berdasarkan masukan pada FGD II. \\
\hline 8. & Validasi Pakar & $\begin{array}{l}\text { Meminta pendapat dan penilaian pakar tentang model yang dihasilkan, } \\
\text { yaitu penilaian pakar terhadap draf model pelatihan yang sudah direvisi } \\
\text { berdasarkan masukan pada FGD I dan II. Validasi bertujuan untuk } \\
\text { mendapatkan masukan dan penilaian pakar serta mengetahui kecocokan } \\
\text { model pelatihan guru yang dikembangkan untuk meningkatkan } \\
\text { kompetensi guru PAI Sekolah Dasar. }\end{array}$ \\
\hline 9. & Revisi III & $\begin{array}{l}\text { Melakukan revisi terhadap draf model berdasarkan masukan dari pakar. } \\
\text { Revisi III dilakukan dengan memperhatikan penilaian, masukan dan } \\
\text { komentar yang diberikan oleh pakar. Revisi dilakukan dengan } \\
\text { menghilangkan hal-hal yang dianggap tidak perlu serta memperkuat hal-hal } \\
\text { yang dianggap lemah. Kemudian muncul model akhir. }\end{array}$ \\
\hline 10. & Menetapkan model akhir & $\begin{array}{l}\text { Menetapkan model akhir pelatihan yang valid berdasarkan uji pakar (uji } \\
\text { konseptual) untuk meningkatkan kompetensi guru PAI Sekolah Dasar }\end{array}$ \\
\hline
\end{tabular}

Berdasarkan tahapan penelitian di atas, maka yang menjadi sumber data penelitian adalah pihak pelaksana pelatihan dari masing-masing instansi pelaksana pelatihan guru, yaitu Kepala Bidang PAI SD di Kantor Wilayah Kementerian Agama Provinsi Sumatera Barat, Kepala Balai Diklat Keagamaan Wilayah Sumatera di Padang dan Panitia Pelaksana PLPG bagi guru PAI SD di Fakutas Tarbiyah dan Keguruan IAIN Imam Bonjol Padang. Alat pengumpul data yang digunakan adalah pedoman observasi, pedoman wawancara, instrumen Focus Group Discussion dan instrumen validasi pakar.

Penelitian ini merupakan kombinasi penelitian deskriptif dan penelitian pengembangan. Oleh karena itu, metode penelitian yang digunakan adalah mixed methods research atau disebut juga metode penelitian yang menunjukkan asumsi filosofis dalam menunjukkan arah tentang cara pengumpulan data, menganalisis data serta perpaduan pendekatan kuantitatif dan kualitatif.

Instrumen penelitian yang digunakan adalah pedoman wawancara, pedoman observasi, instrumen FGD, instrumen validasi dan instrumen analisis dokumentasi. Pemeriksaan keabsahan data dilakukan untuk menjamin bahwa data penelitian yang diperoleh telah dilakukan sesuai dengan prosedur ilmiah. Pemeriksaan keabsahan data juga merupakan bagian yang tidak terpisahkan dari bentuk penelitian kualitatif, dilakukan dengan cara member check, yaitu pengecekan ulang terhadap data yang diperoleh, peer debriefring, yaitu mengadakan diskusi dengan teman sejawat, triangulasi, yaitu pemeriksaan keabsahan data melalui sumber lain, focus group discussion dan uji validasi pakar. Teknik analisis data wawancara meliputi reduksi data, penyajian data, penarikan kesimpulan dan verifikasi. Reduksi data meliputi pengklasifikasian dan pengkodean sesuai dengan jenis data.

\section{HASIL DAN PEMBAHASAN Hasil}

Model pelatihan yang dikembangkan ini memiliki tujuan untuk menghasilkan model pelatihan yang valid untuk meningkatkan kompetensi paedagogik dan profesional bagi guru PAI SD. Manfaat rancang bangun adalah: (1) untuk menjadi pedoman/acuan dalam pelaksanaan pelatihan; (2) membantu menyiapkan komponen pelatihan, bahanbahan dan metoda yang dapat digunakan dalam pelatihan. Secara praktis, hasil penelitian ini diharapkan dapat menjadi bahan diskusi bagi para pengambil kebijakan. Pengambil kebijakan yang dimaksud adalah instansi pemerintah terkait dari tingkat pusat sampai tingkat Kabupaten/Kota, Kepala Sekolah, Pengurus Komite Sekolah, serta Kepala Tata Usaha Sekolah.

Pelaksanaan Pelatihan bagi guru PAI Sekolah Dasar di Sumatera Barat

Hasil penelitian ini menunjukan kondisi lapangan tentang pelatihan yang telah dilaksanakan oleh 3 (tiga) lembaga yang melaksanakan pelatihan untuk meningkatkan 
kompetensi guru Pendidikan Agama Islam di Sumatera Barat, yaitu bimbingan teknis dan pelatihan kurikulum 2013 bagi guru Pendidikan Agama Islam oleh Kepala Seksi Pendidikan Keagamaan Islam di Sekolah dasar Kantor Wilayah Kementerian Agama Provinsi Sumatera Barat (Kepala Seksi Pendidikan Keagamaan Islam di Sekolah Dasar), pelaksana pendidikan dan pelatihan fungsional peningkatan kompetensi guru oleh Balai Pendidikan dan Latihan Kementerian Agama Provinsi Sumatera Barat (Kepala Seksi Teknis Pelaksana Pendidikan dan Pelatihan) dan pelaksana Pendidikan dan Latihan Profesi Guru (PLPG) bagi guru Pendidikan Agama Islam yang akan disertifikasi oleh Fakultas Tarbiyah Institut Agama Islam Negeri (IAIN) Imam Bonjol Padang.

Kegiatan pelatihan yang dilaksanakan bagi guru Pendidikan Agama Islam Sekolah Dasar pada tahun 2013 dan 2014 pada umumnya berkisar pada materi bimbingan teknis pelaksanaan kurikulum 2013. Perencanaan kegiatan dilakukan dengan merancang Term of Reference (TOR) yang memuat kerangka acuan kegiatan implementasi kurikulum 2013 bagi guru PAI di sekolah.

Data di atas sesuai dengan dokumentasi yang diperoleh melalui Term of Reference (TOR) Kegiatan Orientasi Implementasi Kurikulum 2013 bagi Guru PAI dan Budi Pekerti di Sumatera Barat. Perencanaan kegiatan mencakup tentang latar belakang kegiatan pelatihan (yang memuat tentang Undang-Undang, Peraturan Pemerintah, Peraturan Menteri Pendidikan Nasional, Peraturan Menteri Agama dan kebijakan lain yang menjadi landasan dan pedoman dalam pelaksanaan pelatihan kurikulum 2013), gambaran umum kegiatan (yang memuat tentang dasar berfikir perlunya pelatihan tentang bimbingan teknis pelaksanaan kurikulum 2013, kompetensi yang diharapkan dari peserta pelatihan serta pola umum materi dan kegiatan pelatihan yang akan dilaksanakan), penerima manfaat (memuat tentang dampak signifikan orientasi implementasi kurikulum 2013 terhadap proses pembelajaran dan hasil belajar siswa), maksud dan tujuan kegiatan (memuat tentang tujuan penyelenggaraan orientasi implementasi kurikulum 2013, antara lain: 1). Memberikan pemahaman pada peserta tentang rasional Kurikulum 2013, 2) memberikan pemahaman tentang Standar Kompetensi Lulusan (SKL), Kompetensi Inti (KI) dan Kompetensi Dasar (KD), 3). Memberikan pemahaman tentang strategi implementasi kurikulum 2013, 4). Memberikan pemahaman tentang model perancangan pembelajaran PAI, saintifik (scientfic approach) dan penilaian autentik (authenthic assesment) sesuai tuntutan kurikulum 2013, dan 5). Memberikan pemahaman tentang praktek pembelajaran terbimbing.

Perencanaan kegiatan Pendidikan dan Latihan (Diklat) Teknis Fungsional Peningkatan Kompetensi Guru Pertama Mata Pelajaran Pendidikan Agama Islam Sekolah Dasar di Sumatera Barat dirancang dengan nama desain program. Menurut Maswardi (Wawancara: 2016), hal yang perlu diperhatikan dalam menyusun perencanaan kegiatan adalah kebutuhan dan kuota yang tersedia bagi peserta Diklat untuk wilayah Sumbar, Riau dan Jambi. Perencanaan disusun dalam bentuk AKD (Analisis Kebutuhan Diklat).

Sehubungan dengan itu, menurut Siti Afriyanti (Wawancara: 2016), perencanaan kegiatan dan pedoman pelaksanaan Diklat sudah diatur dari pusat. Balai Diklat mengusulkan perencanaan tahunan untuk kegiatan Diklat yang diusulkan melalui rakor. Pada desain program Diklat Teknis Fungsional Peningkatan Kompetensi Guru Pertama Mata Pelajaran Pendidikan Agama Islam Sekolah Dasar dikemukakan bahwa latar belakang pelaksanaan Diklat adalah perlunya peningkatan kompetensi profesional guru melalui pendidikan dan latihan.

Berdasarkan Disain Program Diklat Teknis Fungsional Peningkatan Kompetensi Guru Pertama Mata Pelajaran PAI Sekolah 
Dasar diketahui bahwa sasaran kegiatan Diklat adalah terwujudnya peserta Diklat teknis fungsional peningkatan kompetensi guru pertama mata pelajaran PAI Sekolah Dasar yang memiliki kompetensi sesuai dengan persyaratan Jabatan Fungsional Guru Pertama.

Penyelenggara Pendidikan dan Latihan Profesi Guru (PLPG) di FakultasTarbiyah dan Keguruan IAIN Imam Bonjol Padang telah melakukan beberapa upaya untuk meningkatkan kualitas PLPG. Di antaranya adalah dengan melakukan evaluasi terhadap pelaksanaan pelatihan, yaitu dengan menjalankan angket respon peserta pelatihan terhadap pelaksanaan pelatihan. Angket respon peserta akan dijadikan sebagai bahan evaluasi dan acuan untuk memperbaiki kualitas pelatihan yang berikutnya. Di samping itu, juga dilakukan evaluasi terhadap proses, peserta dan instruktur pelatihan. Sebelum kegiatan PLPG dilaksanakan kegiatan refreshment dan briefing antar narasumber sebelum kegiatan.

Pelaksananaan pelatihan bagi guru PAI SD di Sumatera Barat dilaksanakan oleh lembaga penanggungjawab pelatihan guru pada jajaran Kementerian Agama, yaitu Kanwil Kemenag Provinsi Sumatera Barat, Balai Diklat Keagamaan Provinsi Sumatera Barat dan Fakultas Tarbiyah IAIN Imam Bonjol Padang. Masing-masing lembaga melaksanakan pelatihan bagi guru PAI SD berdasarkan rancangan kegiatan pelatihan yang sudah ditentukan sesuai dengan pedoman yang dikeluarkan oleh panitia pusat. Pelaksanaan pelatihan sudah baik, namun belum didasarkan kepada analisis kebutuhan peserta pelatihan karena tema dan materi pelatihan sudah ditentukan berdasarkan aturan dan petunjuk dari pusat.

\section{Pengembangan Model Pelatihan}

Produk yang dikembangkan adalah model pelatihan berbasis experiental reflecting processsing untuk meningkatkan kompetensi guru Pendidikan Agama Islam Sekolah Dasar di Sumatera Barat. Ciri utama model pelatihan ini adalah bahwa peserta pelatihan belajar berdasarkan pengalaman mereka. Eksplorasi pengalaman bertujuan untuk memacu peserta pelatihan untuk merefleksikan pengalaman mereka untuk memperbaiki proses pembelajaran yang mereka lakukan. Misalnya, peserta pelatihan mengamati kelas, mengingat apa yang telah mereka lakukan sebelumnya, selanjutnya mereka merefleksikan dan mendiskusikan dengan sesama peserta pelatihan. Kemudian mereka mengambil kesimpulan untuk menghasilkan suatu ide bahkan teori untuk perbaikan pelaksanaan pembelajaran. Model ini memiliki 3 (tiga) kelebihan, yaitu: pertama, suasana pelatihan menjadi lebih hidup, karena peserta pelatihan dapat berbagi pengalaman dengan sesama peserta, kedua, peserta pelatihan berperan sebagai mitra pelatih, dimana mereka dapat berbagi pengalaman dan pengetahuan, ketiga, proses refleksi akan dapaat mempertajam pikiran kritis, sehingga dapat membantu mengambil keputusan tentang pelaksanaan pembelajaran di kelas. Model ini akan dapat memperbaiki prinsip-prinsip kerja dan dapat menimbulkan rasa percaya diri peserta pelatihan, sehingga dapat membahas dan mengkritik ide atau pendapat orang lain.

Model yang dihasilkan terdiri atas tiga buah buku yang dapat menjadi acuan dalam pelaksanaan pelatihan untuk meningkatkan kompetensi guru Pendidikan Agama Islam Sekolah Dasar, yaitu:

a. Buku I, tentang Teknis Pelaksanaan Pelatihan yang terdiri atas pendahuluan, dasar hukum, tujuan dan manfaat, sasaran, indikator keberhasilan dan tahapan model pelatihan.

b. Buku II berisi tentang Disain Program Pelatihan yang terdiri atas deskripsi, disain dan program pelatihan yang memuat perencanaan, tujuan pelatihan, materi pelatihan, metode pelatihan, biaya pelatihan, dan evaluasi pelatihan.

c. Buku III berisi tentang bahan ajar pelatihan yang terdiri atas materi pengembangan kebijakan leadership dan kebijakan PAI di sekolah, perubahan mindset kurikulum 2013, karakteristik dan analisis materi PAI, materi substansi mata 
pelajaran PAI, memilih dan menyusun bahan ajar yang kontekstual, model-model pembelajaran PAI di SD, merancang, membuat dan menggunakan media berbasis IT, menyusun silabus dan RPP, perancangan teknik evaluasi pembelajaran PAI SD.

Prototipe model pelatihan yang sudah dikembangkan pelu dilakukan pengayaan melalui kelompok diskusi terfokus yang dilakukan sebanyak 2 kali, yaitu pada hari Sabtu tanggal 01 Agustus 2015 dan Selasa tanggal 18 Agustus 2015 yang bertempat di ruangan kuliah kampus Pascasarjana IAIN Imam Bonjol Padang di Jalan Sudirman, Padang. Peserta pada FGD I diundang sebanyak 11 orang, namun yang berkesempatan hadir adalah sebanyak 8 orang. Sedangkan pada FGD II diundang sebanyak 12 orang dan yang berkesempatan hadir adalah sebanyak 8 orang.

Berdasarkan masukan yang diperoleh dari tahapan FGD, maka dilakukan revisi produk tahap untuk dilanjutkan kepada tahap validasi pakar. Produk yang dihasilkan setelah revisi tahap adalah sebanyak 3 buah

Tabel 2. Rata-Rata Hasil Validasi Model Pelatihan PeningkatanKompetensi Guru PAI SD

\begin{tabular}{|l|l|l|}
\hline No & Aspek yang Dinilai & R \\
\hline 1 & Tujuan & 79,6 \\
\hline 2 & Rasional & 8 \\
\hline 3 & Isi Model & 79,4 \\
\hline 4 & Karakteristik & 78,7 \\
\hline 5. & Kesesuaian dan Bahasa & 79 \\
\hline 6. & Bentuk Fisik & 79 \\
\hline Jumlah & $\mathbf{4 8}$ \\
\hline \multicolumn{2}{|l|}{ Rata-Rata } & $\mathbf{8 0}$ \\
\hline
\end{tabular}

Dari hasil validasi model pelatihan untuk meningkatkan kompetensi guru Pendidikan Agama Islam Sekolah Dasar.yang dinilai oleh validator, seperti pada tabel di atas, dapat diketahui rata-rata hasil validasi secara umum adalah $80,07 \%$ dengan kategori sangat valid. Dari aspek-aspek yang dinilai didapat rata-rata nilai pada tujuan $79,65 \%$, rasional 84,35\%, isi model 79,46 \%, karakteristik 78,72\%, kesesuaian dan bahasa $79,15 \%$ dan bentuk fisik 79, $13 \%$. Pengkategorian hasil validitas model pelatihan untuk meningkatkan kompetensi guru Pendidikan Agama Islam Sekolah Dasar berdasarkan pendapat Riduwan, buku yang terdiri atas Buku I tentang Teknis Pelatihan, Buku II tentang Disain Program Pelatihan dan Buku II tentang materi Ajar Pelatihan yang dilengkapi dengan multi media CD interaktif.

Validasi produk tentang model pelatihan untuk meningkatkan kompetensi guru Pendidikan Agama Islam Sekolah Dasar dilakukan oleh 8 (delapan) orang pakar yang kompeten, yaitu dari Universitas Negeri Padang, IAIN Imam Bonjol Padang, Kanwil Kementerian Agama Provinsi Sumatera Barat dan Kantor Balai Diklat Keagamaan Provinsi Sumatera Barat. Validator memvalidasi produk tentang model pelatihan untuk meningkatkan kompetensi guru Pendidikan Agama Islam Sekolah Dasar yang dibuat dalam 3 (tiga) buah buku, yaitu Buku I berisi tentang Teknis Pelaksanaan Pelatihan, Buku II tentang Disain Model Pelatihan dan Buku III tentang Bahan Ajar Pelatihan.

Data hasil validasi model pelatihan untuk meningkatkan kompetensi guru Pendidikan Agama Islam dari validator disajikan pada tabel sebagai berikut:

\begin{tabular}{|l|l|}
\hline $\begin{array}{l}\text { Rata-Rata Nilai Validasi } \\
(\%)\end{array}$ & Kategori \\
\hline 79,65 & Valid \\
\hline 84,35 & Sangat Valid \\
\hline 79,46 & Valid \\
\hline 78,72 & Valid \\
\hline 79,15 & Valid \\
\hline 79,13 & Valid \\
\hline $\mathbf{4 8 , 0 4 6}$ & Sangat Valid \\
\hline $\mathbf{8 0 , 0 7} \%$ &
\end{tabular}

dimana persentase antara 0\% - 20\% dengan kategori tidak valid, $21 \%$ - $40 \%$ dengan kategori kurang valid, $41 \%$ - $60 \%$ dengan kategori cukup valid, $61 \%$ - $80 \%$ dengan kategori valid, $81 \%-100 \%$ dengan kategori sangat valid.

Dari hasil validasi model pelatihan untuk meningkatkan kompetensi guru Pendidikan Agama Islam Sekolah Dasar yang telah dinilai validator menunjukkan model yang dikembangkan sangat valid. Hal ini berarti bahwa model pelatihan untuk meningkatkan kompetensi guru Pendidikan Agama Islam Sekolah Dasar yang dikembangkan sudah baik dan dapat digunakan sebagai acuan 
dalam pelaksanaan pelatihan untuk meningkatkan kompetensi guru Pendidikan Agama Islam Sekolah Dasar di Sumatera Barat. Namun, masih ada beberapa saran dari validator yang digunakan untuk revisi.

Penilaian umum validator terhadap model pelatihan untuk meningkatkan kompetensi guru Pendidikan Agama Islam Sekolah Dasar.yang dihasilkan adalah dapat digunakan dengan sedikit revisi. Masukan dan saran dari validator sudah diperhatikan dalam menyempurnakan model yang dihasilkan. Hasil validasi secara keseluruhan menunjukkan bahwa model pelatihan.yang dihasilkan telah teruji kualitasnya dan telah dinyatakan sangat valid oleh validator. Menurut Anastasi dan Urbina, dalam Lufri, validitas adalah "suatu ukuran yang menunjukkan bahwa suatu alat ukur dapat mengukur sesuatu yang hendak diukur" (Lufri, 2005). Dengan demikian hasil penilaian validator adalah, semua persyaratan dalam model yang meliputi tujuan, rasionalitas, karakteristik, kesesuaian dan bahasa, isi model dan bentuk fisik sudah sesuai dengan pengkategorian hasil validitas berdasarkan pendapat Riduwan "dimana persentase antara 0\% - 20\% adalah tidak valid, $21 \%-40 \%$ adalah kurang valid, $41 \%$ $60 \%$ adalah cukup valid, $61 \%$ - $80 \%$ adalah valid, $81 \%-100 \%$ adalah sangat valid.

\section{Pembahasan}

Hasil penelitian lapangan tentang pelatihan diperoleh dari 3 (tiga) lembaga yang melaksanakan pelatihan untuk meningkatkan kompetensi guru Pendidikan Agama Islam di Sumatera Barat. Hasil penelitian yang diperoleh adalah penyelenggaraan pelatihan guru PAI SD yang telah dilaksanakan (perencanaan, tujuan pelatihan, materi pelatihan, metode pelatihan, media dan evaluasi pelatihan) mengacu kepada rambu-rambu pelaksanaan pelatihan yang dirancang oleh panitia pusat tanpa memperhatikan kondisi daerah setempat serta faktor pendukung dan penghambat yang ada. Sebaiknya dalam membuat perencanaan pelatihan guru, perlu diperhatikan laporan kegiatan pelatihan sebelumnya dengan mempertimbangkan kebutuhan guru-guru peserta pelatihan. Pelaksana pelatihan guru PAI SD perlu melakukan analisis kebutuhan terhadap peserta yang akan mengikuti pelatihan, karena kebutuhan guru-guru terhadap materi pelatihan cenderung dipengaruhi oleh banyak faktor, di antaranya adalah perkembangan ilmu pengetahuan dan teknologi serta perubahan struktur kurikulum. Pelatihan dalam implementasi kurikulum 2013 penting dilakukan, hal ini bertujuan agar guru paham dengan perubahan yang harus dilakukan sesuai dengan tugas pokok dan fungsinya masingmasing (Yama \& Setiyani, 2016).

Pelatihan guru penting artinya untuk menumbuhkan motivasi untuk perubahan perilaku guru dalam mengajar, sehingga menjadi guru professional, Untuk itu, diperlukan pembinaan yang bertahap dan berkelanjutan (Herianto, 2012). Model pelatihan guru yang sudah dilaksanakan berupa model penataran, di mana guru-guru peserta pelatihan diberikan sosialisasi materi selama 3 (tiga) hari tentang materi pelatihan. Berkenaan dengan penelitian yang telah dilakukan pada lembaga pelaksana pelatihan bagi guru PAI SD, diketahui bahwa model pelatihan yang baik adalah yang didasarkan pada analisis kebutuhan guru-guru terhadap pelatihan. Model ini membutuhkan partisipasi aktif dalam penyelidikan secara ilmiah (Fadriati, 2017).

Pengalaman menjadi aspek penting untuk memperbaiki kualitas pembelajaran. Pembelajaran berbasis pengalaman dapat digunakan untuk mengembangkan kompetensi profesional guru, terutama dalam hal praktik di ruang kelas (Girvan, Conneely, \& Tangney, 2016). Berdasarkan hal tersebut, maka dirancang suatu model pelatihan untuk meningkatkan kompetensi guru PAI SD yang berbasis analisis terhadap pengalaman guru yang bertujuan untuk memacu peserta pelatihan merefleksikan pengalaman mereka dengan tujuan untuk memperbaiki proses pembelajaran. Misalnya, peserta pelatihan 
mengamati kelas, mengingat hal yang dilakukan, merefleksikan dan mendiskusikan dengan sesama peserta pelatihan. Kemudian peserta pelatihan dapat mengambil kesimpulan untuk memperbaiki kualitas pembelajaran yang mereka lakukan.

Di antara fungsi pelatihan adalah memungkinkan sumber daya manusia untuk memunculkan potensi yang dimiliki. Program pelatihan yang baik harus mampu meningkatkan keterampilan mengajar guru (Julifan, 2015). Pelatihan harus meningkatkan pelaksanaan tugas dan pengembangan kompetensi. Model pelatihan guru yang baik, harus mampu meningkatkan kompetensi guru. Salah satu langkah yang diperlukan adalah strategi melaksanakan program pelatihan agar terhindar dari keusangan dan peserta tetap tertarik, dinamis dan bersemangat mengikuti pelatihan. Program pelatihan yang ideal harus terintegrasi dengan tugas dan praktek yang berkesinambungan (Wahira, 2011).

Hasil analisis data menunjukkan bahwa kualitas produk hasil pengembangan, yaitu model pelatihan untuk meningkatkan kompetensi guru Pendidikan Agama Islam Sekolah Dasar.adalah sangat valid. Kesimpulan ini diperoleh melalui focus group discussion I dan II serta uji validasi oleh pakar yang relevan. Uji validasi dilakukan untuk mengetahui keshahihan suatu produk yang telah dikembangkan. Model pelatihan yang dikembangkan te;lah dilakukan uji validitas oleh beberapa validator yang berasal dari pakar pendidikan, pelatihan dan kurikulum, pakar bahasa dan praktisi pelatihan. Validator mengisi lembar validasi yang telah disediakan. Lembar validasi memuat beberapa aspek yang akan dinilai, meliputi aspek tujuan, rasionalitas model, isi model, karakteristik, kesesuaian dan bahasa serta bentuk fisik.

Model pelatihan yang dihasilkan memiliki keterbatasan, yaitu masih terbatas penggunaannya pada pelatihan bagi guru PAI Sekolah Dasar yang dilaksanakan pada Kementerian Agama Provinsi Sumatera Barat. Penelitian yang dilakukan hanya sampai pada tahap uji validitas atau uji konseptual, tidak sampai pada tahap uji lapangan disebabkan karena keterbatasan dana dan faktor pendukung pelaksanaan pelatihan guru. Tidak tertutup kemungkinan pihak lain akan dapat melakukan uji implementasi terhadap model yang dihasilkan.

\section{KESIMPULAN DAN REKOMENDASI}

Model yang dihasilkan terdiri atas tiga buah buku yang dapat menjadi acuan dalam pelaksanaan pelatihan untuk meningkatkan kompetensi guru Pendidikan Agama Islam Sekolah Dasar, yang terdiri atas Buku I tentang Teknis Pelatihan, Buku II tentang Disain Program Pelatihan dan Buku III tentang materi Ajar Pelatihan yang dilengkapi dengan multimedia CD interaktif. Validasi produk tentang model pelatihan untuk meningkatkan kompetensi guru Pendidikan Agama Islam Sekolah Dasar dilakukan oleh 8 (delapan) orang pakar yang kompeten. Hasil validasi tentang model pelatihan.yang dinilai oleh validator diperoleh rata-rata hasil validasi secara umum adalah 80,07\% dengan kategori sangat valid. Dari aspek-aspek yang dinilai didapat rata-rata nilai pada tujuan $79,65 \%$, rasional $84,35 \%$, isi model $79,46 \%$, karakteristik 78,72\%, kesesuaian dan bahasa $79,15 \%$ dan bentuk fisik $79,13 \%$.

Pengembangan model pelatihan ini mempunyai implikasi bahwa peningkatan kompetensi guru dapat ditempuh melalui pelatihan guru. Pelatihan yang berkualitas akan dapat menghasilkan guru yang unggul, tangguh, berteknologi tinggi dan memiliki kompetensi yang memadai sehingga mampu berkompetisi dan berprestasi. Pelaksanaan pelatihan guru membutuhkan perencanaan yang matang yang didasarkan kepada analisis kebutuhan guru, materi ajar pelatihan yang memadai, strategi dan metode pelatihan yang tepat dan efektif, sehingga guru-guru mampu menyelenggarakan kegiatan pembelajaran dengan baik dan mampu merespon kebutuhan peserta didik dan pembelajaran pada umumnya. Setiap 
kegiatan pelatihan membutuhkan dukungan dan perhatian dari berbagai pihak yang terkait agar tercapai peningkatan kualitas guru yang diharapkan. Betapapun bagusnya model pelatihan yang dihasilkan, apabila tidak ada perhatian dan dukungan dari pihak yang terkait, maka tidak akan berati apa-apa (Fadriati, 2014). Guru Pendidikan Agama Islam harus memiliki kualifikasi akademik, kompetensi keguruan dan sertifikat profesional. Namun masih ada guru PAI yang sudah memiliki kualifikasi dan sertifikat pendidik, namun kompetensinya masih jauh dari memadai. Atas dasar ini, fokus pembinaan pemerintah terhadap guru PAI SD, terutama guru yang sudah bersertifikat adalah meningkatkan kompetensi guru melalui pelatihan.

\section{REFERENSI}

Akarawang, C., Kidrakran, P., \& Nungchalerm, P. (2017). Developing ICT Competency for Thai Teachers through Blended Training. Journal of Education and Learning (EduLearn), 10(1), 15. https://doi.org/10.11591/edulearn.v10i1.2 830

Anisah. (2014). Pengaruh Pelatihan terhadap Produktivitas Guru PNS pada SMPN 15 Kota Jambi. Jurnal Ilmiah Universitas Batanghari Jambi, 14(2), 1-5. Retrieved from

http://ir.obihiro.ac.jp/dspace/handle/1032 2/3933

Carr, D. (1999). Professional education and professional ethics right to die or duty to live? Journal of Applied Philosophy, 16(1), 33-46.

Chew, L. C. (2016). Teacher Training and Continuing Professional Development: the Singapore Model. In Prosiding ICTTE FKIP UNS 2015 (Vol. 1, pp. 165171).

Fadriati. (2014). Strategi dan Teknik Pembelajaran PAI Pengarang. In STAIN Batusangkar Press (pp. 1-208).

Fadriati. (2017). A Model of Discovery Learning Based-Text Book of Character and Islamic Education: An Accuracy
Analysis of Student Book in Elementary School. Ta'dib, 20(2), 188-201. Retrieved from http://ecampus.iainbatusangkar.ac.id/ojs/i ndex.php/takdib/index

Fitria, Happy, Dkk., Upaya Meningkatkan Kompetensi Guru melalui Pelatihan Penelitian Tindakan Kelas, Abdimas Unwahas, Vol. 4,No. 1, April, 2019

Gall, M. D., \& Borg, W. R. (2003). Educationnal Research: And Introduction., 2003. In USA: Pearson Education.

Girvan, C., Conneely, C., \& Tangney, B. (2016). Extending experiential learning in teacher professional development. Teaching and Teacher Education, 58(August), 129-139. https://doi.org/10.1016/j.tate.2016.04.009

Herianto, E. (2012). Pembinaan Pasca Pelatihan dalam Pembentukan Perilaku Profesional Keguruan Di Madrasah Ibtidaiyah. Sekolah Dasar, 21(2), 167177.

Julifan, J. A. (2015). Efektivitas manajemen pendidikan dan pelatihan berbasis kompetensi bagi guru. Jurnal Administrasi Pendidikan, 22(2), 1-12.

Lufri. (2005). Buku Ajar Metodologi Penelitian. In Padang: UNP,.

Nurdin, S., \& Adriantoni. (2016). Kurikulum dan Pembelajaran. In Jakarta: RajaGrafindo Persada (pp. 1-401).

Subadi, T., \& Dahroni, D. (2017). Model Pelatihan Guru Ilmu Pengetahuan Sosial Di Smp Muhammadiyah Kartasura. Scholaria: Jurnal Pendidikan Dan Kebudayaan, $\quad 7(1), \quad 26$. https://doi.org/10.24246/j.scholaria.2017. v7.i1.p26-34

Suhandi, Deni, dan Julia, Identifikasi Kompetensi Guru sebagai Cerminan Profesionalisme Tenaga Pendidik di Kabupaten Sumedang (Kajian Kompetensi Paedagogik), Mimbar Sekolah Dasar, Volume 1 Nomor Tahun 2014.

Wahira. (2011). Pengembangan Model Pelatihan Apresiasi Seni Tari Tradisi 
Lokal pada Guru di Sekolah Dasarr. Penelitian Dan Pendidikan, 29(2), 149157.

https://doi.org/10.1016/j.psc.2017.05.005 Yama, S. F., \& Setiyani, R. (2016). Pengaruh Pelatihan Guru, Kompetensi Guru dan
Pemanfaatan Sarana Prasarana terhadap Kesiapan Guru Prodi Bisnis Manajemen dalam Implementasi Kurikulum 2013. Economic Education Analysis Journal, 5(1), 85-99. 